\title{
Effect of Ergonomic Factors on Employees Performance in Nigeria's Banking Sector
}

\author{
Asogwa Ogochukwu Sheila \\ Department of Business Administration, Nnamdi Azikiwe University, Awka, Anambra State, Nigeria \\ Ndubuisi-Okolo Purity.U.(Ph.D) \\ Department of Business Administration, Nnamdi Azikiwe University, Awka, Anambra State, Nigeria
}

\begin{abstract}
The study examined the effect of ergonomic factors on employees' performance in the Nigerian banking sector, using banks in Anambra State, Nigeria as the study area. In investigating the effects of these factors on employees' performance, we raised a literature review and partitioned it into three main sections of conceptual review, theoretical exposition and empirical review. The study adopted descriptive survey design and the main statistical tool of analysis were Summary Statistics and Chi-Square $\left(\chi^{2}\right)$ test of independence. All tests were conducted at 0.05 level of significance. Major findings from the study were that physical workplace environment significantly affects employees' performance in the banking sector in Nigeria. Similarly, the study found also that engaging on repetitive task assignment and insufficient rest time hampers employees' performance. The study concludes that having work/task design that are repetitive makes employees feel tired and bored and that insufficient rest time for the employees also leads to health conditions that negatively affects performance in the banking industry in Nigeria. It was recommended among others that the management should encourage the employees to perform better by providing conducive workplace environment both in design of tasks and indoor office environment.
\end{abstract}

Keywords: Ergonomic factors, Employees’ performance, Banking sector, Nigeria.

DOI: $10.7176 / \mathrm{EJBM} / 12-23-10$

Publication date:August $31^{\text {st }} 2020$

\subsection{Background to the Study}

The personnel or employees are the most valuable asset of any business organization and as such, serious attention ought to be given to workplace conditions under which they employees perform their respective tasks as prerequisites for improving their performance and outcomes (Yankson, 2012). In recognition of the above, the past few decades have witnessed a strong trend in corporate organizations and businesses reconfiguring the spaces of their offices in new ways and models. This shift towards more exciting and flexible workplace environment and the need to met the diverse and growing expectations and requirements of different employees has led to rising debates about how and where work is accomplished (Asante, 2012). It has been overtly stated that the kind of workplace environment/conditions the management provides for the employees speak volume of the value it places on the employees.

In the opinion of Yankson (2012), there are two fundamental factors which affect employees' performance and productivity and they include management driven factors and those that arise from work premises. Management driven factors according to him are: the development of organizational plans such as the allocation of responsibilities at all levels of the organization, the definition of job description, degree of access to the management and the administrative support needed to complete tasks, working patterns, shift working, break times, absence of holiday over and health as well as safety policies, including the provision of training and development of safe working practices and adequate supply of protective clothing and equipment. On the other hand, other factors that enhance performance and productivity of the employees include office or factory design, machinery and workshop tools, workspace availability, lighting/illumination of the offices, weather, temperature ventilation, humidity, noise, vibration, hygiene, welfare facilities availability and standard of office furniture. It has become very necessary and fashionable for offices to be configured in a manner that maximizes employees' interaction and collaboration while on duty.

Ergonomics is viewed by many authors in the field among who were Vimalanathan and Babu (2017), as the means of equipping employees to improve on their performance and also to ensure their safety within the work environment. As a systematic attempt to make work environment safe, stonner, Freeman and Gilbert (2006) note that it is the science of designing a work station to fit tasks of a particular employee and also create comfort rather than confining the employees to suit the tasks. It has also been observed that erognomics help to create alignment between the physical office work environment and the business objects as well as the mission of the organization. The measure of success of this alignment, however, is referred to as organizational effectiveness (Pawar, and Khedkar, 2016). Furthermore, conducive work environment in all ramifications will reduce complaints and rate of negative work behaviours by employees. Roelofsen (2002) suggests that ergonomic is important because when an employee performs specific task overtime, the body becomes tensed by awkward posture thereby exhibiting 
symptoms such as fatigue, discomfort, pains and stress thus leading to musculoskeletal disorder which affects performance at the duty post. In the light of the above, the study aims at determining the effect of ergonomic factors on employees' performance in the Nigerian banking sectors with particular interest on effect of physical work environment, effect of high repetitive tasks and effect of insufficient rest break on employees' performance in the organization.

\subsection{Statement of the Problem}

The employees are the bedrock of any organization in terms of survival, profit-making (if a profit making organization) and sustainability. This, perhaps, could be the reason for emphasis on well-designed and furnished offices for the employees. In addition, it signals the values and objectives of the organization as well as communicates the company's strategic and overall corporate goals to both the employees and clients. In practice, it appears many organizations, including banks do not pay much attention to their workplace environment and processes and as a result, a number of employees are suffering from various degrees of back, spine, neck and stress related ailments. In the mist of all the challenges at the workplace, management however expects employees of all categories to put up enhanced performance towards the realization of set corporate goals. Given the prevailing situation, it has become necessary to examine how the ergonomic factors influence employees' performance in the organization.

\subsection{Objectives of the Study}

The broad objective of the study is to examine the effect of ergonomic factors on employees' performance in the banking sector in Nigeria. But the specific objectives are to:

(i) Determine the effect of physical workplace environment on employees' performance in the organization.

(ii) Ascertain the effect of high repetitive tasks on employees' performance in the organization.

(iii) Evaluate the effect of insufficient rest time (break) on employees' performance in the organization.

\subsection{Research Questions}

The following research questions were raised to guide the study:

(i) What is the effect of physical workplace environment on employees' performance in the organization?

(ii) How do high repetitive tasks affect employees' performance in the organization?

(iii) What is the effect of insufficient rest time (break) on employees' performance in the organization?

\subsection{Statement of Hypotheses}

The following null hypotheses were formulated to guide the objectives of the study and strengthen the analysis:

(i) Physical workplace environment does not negatively and significantly affect employees' performance in the organization.

(ii) High repetitive task does not have negative and significant effect on employees performance in the organization.

(iii) Insufficient rest time (break) does not negatively and significantly affect employees' performance in the organization.

\subsection{Significance of the Study}

The study is significant because its findings will be of immense benefit to the stakeholders in the banking industry. For instance, the management would be sufficiently enlightened on the need to provide conducive workplace for the employees so as to obtain optimal performance from them. On the other hand, from the theoretical perspective, the study will add to the existing stock of literature in the area thereby expanding the frontiers of knowledge.

\section{REVIEW OF THE RELATED LITERATURE \\ 2.1 Conceptual Review}

\subsubsection{Concept of Ergonomics}

Ergonomics is an applied science concerned with designing and arranging things employee use so that the employee and things interact most efficiently and safely to produce enhanced performance (Pawar and Khedkar, 2016). In a related development, the International Ergonomics Association (2012) defines ergonomics as the scientific discipline concerned with the understanding of interactions among humans and other elements of a system and the profession that applies theory principles, data and method of design to optimize human well-being and overall system performance. The association observes that ergonomics is the major determinant of employee's productivity within the organization and adjusting physical ergonomics with an organization to match employee's posture, provides suitable environment and hence improved performance. Similarly, "Understanding Ergonomics at Work" which is a publication of Health and Safety Executive (HSE), UK in 2003 defines ergonomics as the scientific study of human work. It considers the physical and mental capabilities and limits of the worker as he/she 
interacts with tools, equipment, work methods, tasks and working environment. The publication also posits that the application of ergonomics to workplace improves health and safety by reducing the potentials for accident, injury, ill-health and improves performance and productivity of the employees.

\subsubsection{Concept of Employee Performance}

In order to achieve competitive advantage and profitability in business environment, every organization aspires to have highly performing employees. For this reason, in trying to conceptualize employee performance, Aguinis (2009) differentiates between an action (i.e. behavioural) aspect and an outcome aspect of performance. The behavioural aspect refers to what an employee does in the work situation. It encompasses behaviours such as assembling parts of a car engine, selling personal computers, teaching basic reading skills to elementary school children, servicing customers at the work or performing open heart surgery. The outcomes aspect refers to the consequence or result of the individual's behaviour. The above describes behaviours may result in outcomes such as number of engines assembled, pupils' reading proficiency, sales figures, successful number of bank customers served or number of successful heart operations. Consequently, employee performance can therefore be defined as the extent to which organizational members contribute to the realization of the organization's goals.

\subsection{Theoretical Exposition}

Designing ergonomics and convenient location increases employees' motivation, satisfaction and performance considerably (Hameed and Amjord, 2009). Similarly, Lablebici (2012) posits that the workplace environment plays vital role for the employees within the organization and the quality of workplace environment is what determines employees' performance and productivity. It has been demonstrated that employees assess how much value their employers place on them through the conditions of their workplace environment (Deouskar, 2017). Office ergonomics has been recommended by many studies as one of the ways of equipping employees at workplace to help produce best performance. The idea is that quality of employees' workplace environment has most influence on the level of employee's motivation and subsequently performance. It goes without the saying that organizations, especially those in the service industry like banks, that recognize provision of conducive physical office environment necessary will no doubt enjoy the commitment and cooperation of the workforce more than those who do not (Alok and Shweta, 2011).

Sekar (2011) notes that the relationship between work, the workplace and the tools of work becomes an integral part of work itself. He continued that the management which dictates how, exactly to maximize employees productivity, centers around two major areas of focus: personal motivation and the infrastructural of the work environment.

As Moran (2012) notes, health risks posed by poor posture and repetitive tasks in the office are too important to be ignored by the management. In his article "Home Office Ergonomics", he analysed how the lack of ergonomic principles in the office can negatively affect some of the key human body parts i.e., the eye, neck, wrist, arms, back, hips, legs, knees, feet, etc. In his final submission, he observes that wrong positioning of any of the human parts outlined above could lead to unpleasant health conditions thereby affecting performance negatively. Therefore, it is not only in the interest of the employees to ensure that ergonomic factor are given best attention but also it is in the interest of the organization given the effect on productivity. On the other hand, repetitive tasks, frequent use of arm, hand or fingers which have been identified as another area of dissatisfaction to the employees hinders effective performance in the organization (Zafir, et al, 2011). In addition to repetitive tasks and boredom that accompanies it, insufficient rest time has serious health implications which includes stress, fatigue, ache, etc, all of which impacts negatively on performance and productivity (Pickson et al, 2017).

\subsection{Empirical Review}

Deshpande (2015) carried out a study on ergonomics and its stress relating issues for the employees working in banks in Gujarat. He uses descriptive survey design for the study. Findings from the study revealed that office design is very vital in terms of increasing employees' productivity. He concludes that comfortable and ergonomic office design motivates the employees and increases their performance substantially. In a related study, Saleem, Shah, Zaman, Arif, Shehzad and Ullah (2012) investigated the impact of interior physical environment on academicians' productivity in Pakistani high education institutions. The result of the study affirmed that office design is very vital in terms of enhancing employee productivity. They concluded that comfortable and contented office design influences the employees to increase their performance. In a cross-sectional study, Jayaweera (2015) assessed the relationship between work environmental factors and job performance with work motivation using 254 hotel workers in twenty-five chain hotels in England. The study found that work motivation was a significant influence on job performance. It was concluded that decent working conditions enhances motivation and consequently job performance.

Krishnamoorthy, Kronenburg, Shetterly and Gaitlard (2016) explored the relationship between indoor work environment and employee perception of health-related symptoms in an office environment. The study found that conduciveness of air temperature and air quality has significant positive influence on employee well-being, 
workload and productivity. Pickson, Bannerman and Ahwireng (2017) investigated the effect of ergonomics on employee productivity in butchering and trimming line of pioneer food cannery in Ghana. The study used descriptive survey design and the result shows that all indicators of work ergonomics have significant and positive correlation with employee productivity in pioneer food cannery Ghana. Zafir, Syed, Shaza and Norliza (2011) did a study on ergonomics and work stress issues in the banking sector. The study adopted descriptive survey design and the result indicate that the problems of body postures and health factors under the ergonomically designed workstation contributed to the work stress outcomes in the department. The study concludes that having a competent and healthy workforce will surely contribute to human capital development and the overall organization's success.

Hameed (2009) carried out a study on impact of office design on employee's productivity: a study of banking organizations in Abbottabad. The study used descriptive survey design as the method and the result of the analysis revealed that office design has significant impact on employees productivity. The study concludes that the measure management in designing the offices and tasks for the employees is the measure realized later on in productivity. In a related study, Taiwo (2010) investigated the effect of work environment on employees' performance, using selected oil and gas industries in Lagos State, Nigeria as the study area. The study was a cross-sectional survey. The results indicate that the elements of workplace environment of the organization are strongly correlated with the performance of the organization. The study concludes that the state of workplace environment in any organization is a true reflection of the value management places on the employees.

\section{METHODOLOGY}

\subsection{Research Design}

The study adopted descriptive survey design because only a part of the population was studied with the intention of generalizing the results for the entire population of interest. Besides, Ikeagwu (1997) in Ejike (2016) notes that studies of this nature would use the survey method to look for information on facts regarding attitudes, practices and opinion of the respondents on given issues of interest.

\subsection{Area of the Study and Population}

The study covered senior bank personnels in Anambra State and a total of 931 of the specified category were identified through a pilot study commissioned by the researcher across the three industrial zones of Awka, Onitsha, Nnewi and environs in the state. Breakdown of the figure shows that Awka has 329, Onitsha 305 and Nnewi 297. Thus 931 senior bank staff in Anambra State constitutes the population for the study.

\subsection{Sample Size Determination and Selection Procedure}

This study applied Taro Yameni's statistical formula for determining sample size as follows:

Where:

$$
n=\frac{N}{1+N(e)^{2}}
$$

$$
\begin{array}{ll}
\mathrm{n} & =\text { Sample size to be determined } \\
\mathrm{N} & =\text { Entire population of interest } \\
\mathrm{e} & =\text { Error margin (0.05) } \\
1 & =\text { Constant (unity) }
\end{array}
$$

Substituting the values in the formular, we have:

$$
\begin{aligned}
& n=\frac{931}{1+931(0.05)^{2}}=279.789631855 \\
& n=280(\text { Nearest } \text { whole number })
\end{aligned}
$$

Thus 280 senior level personnel is the study sample.

Table 3.1:Population and Sample Allocation to Zones

\begin{tabular}{lllll}
\hline S/N & Zone & Population & Sample Allocation & Percentage of Total \\
\hline 1. & Awka & 329 & 99 & 35.3 \\
2. & Onitsha & 305 & 92 & 32.8 \\
3. & Nnewi & 297 & 89 & 31.9 \\
\hline & Total & 931 & 280 & 100.0 \\
\hline
\end{tabular}

Source: Field Survey, 2020

Table 3.1 shows that sample was allocated to zones proportionately depending on the population senior bank staff in the zone. In terms of selecting the units of observation, convenience method was used because of the disperse nature of the population. 


\subsection{Instrument for Data Collection and Reliability Test}

An item structured instrument which was designed in a Likert scale format was used to elicit information from the respondents by the researcher. The instrument was validated by experts in the field. It was equally tested for reliability through the method of test re-test. Through the application of Spearman rank order correlation, coefficients of $0.90,0.80$ and 0.80 were found for the three research questions respectively with an average coefficient 0.83 which means that the instrument is 83 percent reliable.

\subsection{Method of Data Collection and Analysis}

Direct questionnaire distribution method was adopted in collecting the primary data and it afforded the researcher the opportunity of assessing whether the respondents actually understood the questionnaire items. It also helped in reducing the volume of non-response which often associate with surveys of this nature. Out of the 280 copies of the questionnaire shared out, 273 were completed and returned thus showing a response rate of 97.5 percent and it was considered very adequate. Concerning the method of data analysis, summary statistics and chi-square $\left(\chi^{2}\right)$ test of independence were used in analyzing the data. All tests were conducted at 0.05 level of significance.

\section{DATA PRESENTATION AND ANALYSIS}

\subsection{Demographic Characteristics of the Respondent}

Respondents background information of the respondents such as gender, age, education and organizational tenure were analyzed in this section of the analysis.

\section{Table 4.1:Demographic Features of the Respondents}

\begin{tabular}{|c|c|c|c|c|}
\hline $\mathrm{S} / \mathrm{N}$ & Demographic Features & & Frequency & $\begin{array}{l}\text { Percentage of } \\
\text { Total }\end{array}$ \\
\hline \multirow[t]{3}{*}{1.} & Gender: & Male & 121 & 44.3 \\
\hline & & Female & 152 & 55.7 \\
\hline & & Total & 273 & 100.0 \\
\hline \multirow[t]{6}{*}{2.} & Age Bracket: & $18-27$ years & 42 & 15.5 \\
\hline & & 28-37 years & 96 & 35.1 \\
\hline & & $38-47$ years & 72 & 26.3 \\
\hline & & 48-57 years & 47 & 17.2 \\
\hline & & 58 and above years & 16 & 5.9 \\
\hline & & Total & 273 & 100.0 \\
\hline \multirow[t]{7}{*}{3.} & Educational Attainment: & & & \\
\hline & & Diploma & 47 & 17.3 \\
\hline & & First degree & 159 & 58.2 \\
\hline & & Professional Cert. & 35 & 12.8 \\
\hline & & Masters degree & 30 & 11.0 \\
\hline & & Ph.D & 2 & 0.7 \\
\hline & & Total & 273 & 100.0 \\
\hline \multirow[t]{6}{*}{4.} & Organizational Tenure: & & & \\
\hline & & Less than 5 years & 58 & 21.2 \\
\hline & & $5-10$ years & 79 & 28.9 \\
\hline & & $11-15$ years & 87 & 31.9 \\
\hline & & 16 and above years & 49 & 17.9 \\
\hline & & Total & 273 & 100.0 \\
\hline
\end{tabular}

Source: Field Survey, 2020

Table 4.1 shows that female respondents constitute 55.7 percent of the sample. It shows further that age bracket of 28 years and above constitutes about 84.5 percent of the sample. In terms of educational attainment of the respondents, the analysis shows that 69.2 percent have qualifications ranging from first degree and above while 17.3 percent and 12.8 percent have diploma and professional certificates respectively. With respect to organizational tenure, close to 80 percent of them have worked in the industry for upward of 5 years and above. From the results of the analysis, it can be stated unequivocally that the respondents can effectively discuss all issues surrounding the ergonomic factors and their performance, especially when we consider their educational qualification and length of time in the industry.

\subsection{Ergonomic Factors and Employees' Performance}

All issues relating to influence of ergonomics on employees' performance (physical workplace environment, equipment and furniture, work design, etc) are presented in a Likert scale format and analyzed in this section through summary statistics of percentages. 
Table 4.2:Physical Workplace Environment and Employee Performance

\begin{tabular}{|c|c|c|c|c|c|c|c|}
\hline \multirow[t]{2}{*}{$\mathrm{S} / \mathrm{N}$} & \multirow[t]{2}{*}{ Items of the Questionnaire } & \multicolumn{5}{|c|}{ Likert Scale Options } & \multirow[t]{2}{*}{ Total } \\
\hline & & SA & A & $\mathrm{D}$ & SD & UND & \\
\hline 1. & $\begin{array}{l}\text { When one office is sufficiently equipped with } \\
\text { appropriate and standard furnitures, the employees will } \\
\text { perform optimally. }\end{array}$ & $\begin{array}{l}92 \\
(33.7)\end{array}$ & $\begin{array}{l}136 \\
(49.8)\end{array}$ & $\begin{array}{l}20 \\
(7.3)\end{array}$ & $\begin{array}{l}15 \\
(5.5)\end{array}$ & $\begin{array}{l}10 \\
(3.7)\end{array}$ & $\begin{array}{l}273 \\
100\end{array}$ \\
\hline 2. & $\begin{array}{l}\text { In this age of IT, functional computer units and other IT } \\
\text { equipment are very necessary for effective } \\
\text { performance. }\end{array}$ & $\begin{array}{l}107 \\
(39.2)\end{array}$ & $\begin{array}{l}125 \\
45.8)\end{array}$ & $\begin{array}{l}20 \\
(7.3)\end{array}$ & $\begin{array}{l}11 \\
(4.0)\end{array}$ & $\begin{array}{l}10 \\
(3.7)\end{array}$ & $\begin{array}{l}273 \\
100\end{array}$ \\
\hline 3. & $\begin{array}{l}\text { When an office is properly illuminated couple with } \\
\text { adequate air flow, workers would be happy in the office. }\end{array}$ & $\begin{array}{l}111 \\
(40.7)\end{array}$ & $\begin{array}{l}120 \\
(44.0)\end{array}$ & $\begin{array}{l}25 \\
(9.2)\end{array}$ & $\begin{array}{l}10 \\
(3.7)\end{array}$ & $\begin{array}{l}7 \\
(2.6)\end{array}$ & $\begin{array}{l}273 \\
100\end{array}$ \\
\hline 4. & $\begin{array}{l}\text { With good spatial arrangement in the office, work is } \\
\text { made a great delight for the workers. }\end{array}$ & $\begin{array}{l}121 \\
(44.3)\end{array}$ & $\begin{array}{l}109 \\
(40.0)\end{array}$ & $\begin{array}{l}26 \\
(9.5)\end{array}$ & $\begin{array}{l}10 \\
(3.7)\end{array}$ & $\begin{array}{l}7 \\
(2.6)\end{array}$ & $\begin{array}{l}273 \\
100\end{array}$ \\
\hline 5. & $\begin{array}{l}\text { Workplace flexibility in terms of access to easy } \\
\text { communication and other accessories reduces job } \\
\text { hazards. }\end{array}$ & $\begin{array}{l}105 \\
(28.5)\end{array}$ & $\begin{array}{l}130 \\
(47.6)\end{array}$ & $\begin{array}{l}19 \\
(7.0)\end{array}$ & $\begin{array}{l}10 \\
(3.7)\end{array}$ & $\begin{array}{l}9 \\
(3.3)\end{array}$ & $\begin{array}{l}273 \\
100\end{array}$ \\
\hline & Total & 536 & 620 & 110 & 56 & 43 & 1365 \\
\hline & Percentage of Total & $(39.3)$ & $(45.4)$ & $(8.1)$ & $(4.1)$ & $(3.2)$ & 100 \\
\hline
\end{tabular}

Note: Figures in parenthesis are percentages

: $(\mathrm{SA}=$ Strongly agree; $\mathrm{A}=$ Agree; $\mathrm{D}=$ Disagree, $\mathrm{SD}=$ Strongly disagree and UND = Undecided $)$

From Table 4.2, 39.3 percent of the respondents on the average agreed that inadequate physical workplace environment negatively affects employees performance, 45.4 percent strongly agreed, 8.1 percent of them disagreed, 4.1 percent strongly disagreed while 3.2 percent of them had no opinion on all the issues raised in the section. But the variations across the items shows that whereas 33.7 percent and 49.8 percent strongly and merely agreed with item 1, 40.7 percent and 44.3 percent did so respectively for item 4.

Table 4.3:High Repetitive Tasks and Employees' Performance

\begin{tabular}{|c|c|c|c|c|c|c|c|}
\hline \multirow[t]{2}{*}{$\mathrm{S} / \mathrm{N}$} & \multirow[t]{2}{*}{ Items of the Questionnaire } & \multicolumn{5}{|c|}{ Likert Scale Options } & \multirow[t]{2}{*}{ Total } \\
\hline & & SA & A & $\mathrm{D}$ & $\mathrm{SD}$ & UND & \\
\hline 1. & $\begin{array}{l}\text { Job designs that are highly repetitive in nature does not } \\
\text { give employees room for taking initiative and it } \\
\text { negatively affects employees performance. }\end{array}$ & $\begin{array}{l}112 \\
(41.0)\end{array}$ & $\begin{array}{l}121 \\
(44.3)\end{array}$ & $\begin{array}{l}20 \\
(7.3)\end{array}$ & $\begin{array}{l}15 \\
(5.5)\end{array}$ & $\begin{array}{l}5 \\
(1.8)\end{array}$ & $\begin{array}{l}273 \\
100\end{array}$ \\
\hline 2. & $\begin{array}{l}\text { Office works that are physically exhaustive reduces } \\
\text { employees performance and productivity in the service } \\
\text { sector. }\end{array}$ & $\begin{array}{l}105 \\
(38.5)\end{array}$ & $\begin{array}{l}130 \\
(47.6)\end{array}$ & $\begin{array}{l}25 \\
(9.2)\end{array}$ & $\begin{array}{l}8 \\
(2.9)\end{array}$ & $\begin{array}{l}5 \\
(1.8)\end{array}$ & $\begin{array}{l}273 \\
100\end{array}$ \\
\hline 3. & $\begin{array}{l}\text { Repetitive tasks for a long time does not encourage } \\
\text { employees' development and it impedes performance. }\end{array}$ & $\begin{array}{l}126 \\
(46.2)\end{array}$ & $\begin{array}{l}109 \\
(39.9)\end{array}$ & $\begin{array}{l}20 \\
(7.3)\end{array}$ & $\begin{array}{l}10 \\
(3.7)\end{array}$ & $\begin{array}{l}8 \\
(2.9)\end{array}$ & $\begin{array}{l}273 \\
100\end{array}$ \\
\hline 4. & $\begin{array}{l}\text { Repetitive tasks demotivates and some times it leaves } \\
\text { task uncompleted thereby reducing productivity. }\end{array}$ & $\begin{array}{l}108 \\
(39.6)\end{array}$ & $\begin{array}{l}125 \\
(45.8)\end{array}$ & $\begin{array}{l}22 \\
(8.1)\end{array}$ & $\begin{array}{l}10 \\
(3.7)\end{array}$ & $\begin{array}{l}8 \\
(2.9)\end{array}$ & $\begin{array}{l}273 \\
100\end{array}$ \\
\hline 5 . & $\begin{array}{l}\text { Work design that is not in conformity with the desires } \\
\text { of the worker leads to health issues. }\end{array}$ & $\begin{array}{l}101 \\
(37.0) \\
\end{array}$ & $\begin{array}{l}112 \\
(41.0) \\
\end{array}$ & $\begin{array}{c}29 \\
(10.6) \\
\end{array}$ & $\begin{array}{l}20 \\
(7.3) \\
\end{array}$ & $\begin{array}{l}11 \\
(4.0)\end{array}$ & $\begin{array}{l}273 \\
100 \\
\end{array}$ \\
\hline & Total & 552 & 597 & 116 & 63 & 37 & 1365 \\
\hline & Percentage of Total & $(40.4)$ & $(43.7)$ & $(8.5)$ & $(4.6)$ & $(2.7)$ & 100 \\
\hline
\end{tabular}

Note: Figures in parenthesis are percentages

: $(\mathrm{SA}=$ Strongly agree; $\mathrm{A}=$ Agree; $\mathrm{D}=$ Disagree, $\mathrm{SD}=$ Strongly disagree and UND = Undecided $)$

The analysis presented in Table 4.3 shows that 40.4 percent of the respondents on the average strongly agreed that highly repetitive tasks impedes employee performance, 43.7 percent merely agreed, 8.3 percent disagreed, 4.6 percent strongly disagreed and 2.7 percent were undecided on all the issues raised. However, the variation across the items showed that 41 percent strongly agreed and 44.3 percent merely agreed with item 1 while 38.5 percent and 47.6 percent strongly and merely agreed with item 2 . 
Table 4.4:Insufficient Rest Time Break and Employees' Performance

\begin{tabular}{|c|c|c|c|c|c|c|c|}
\hline \multirow[t]{2}{*}{$\mathrm{S} / \mathrm{N}$} & \multirow[t]{2}{*}{ Items of the Questionnaire } & \multicolumn{5}{|c|}{ Likert Scale Options } & \multirow[t]{2}{*}{ Total } \\
\hline & & SA & A & $\mathrm{D}$ & SD & UND & \\
\hline 1. & $\begin{array}{l}\text { When faced with long working hours, employees feel } \\
\text { dissatisfied and it negatively affects performance. }\end{array}$ & $\begin{array}{l}90 \\
33.0)\end{array}$ & $\begin{array}{l}108 \\
(39.6)\end{array}$ & $\begin{array}{c}40 \\
(14.7)\end{array}$ & $\begin{array}{l}20 \\
(7.3)\end{array}$ & $\begin{array}{l}15 \\
(5.5)\end{array}$ & $\begin{array}{l}273 \\
100\end{array}$ \\
\hline 2. & $\begin{array}{l}\text { Long hours of work in front of a computer monitor } \\
\text { raises some health issues with the eyes of the worker. }\end{array}$ & $\begin{array}{l}101 \\
(37.0)\end{array}$ & $\begin{array}{l}109 \\
(40.0)\end{array}$ & $\begin{array}{c}30 \\
(11.0)\end{array}$ & $\begin{array}{l}20 \\
(7.3)\end{array}$ & $\begin{array}{l}13 \\
(4.8)\end{array}$ & $\begin{array}{l}273 \\
100\end{array}$ \\
\hline 3. & $\begin{array}{l}\text { Insufficient rest time/break does not give room for } \\
\text { proper relaxation to refresh and come back for good } \\
\text { performance. }\end{array}$ & $\begin{array}{l}122 \\
(44.7)\end{array}$ & $\begin{array}{l}120 \\
(44.0)\end{array}$ & $\begin{array}{l}20 \\
(7.3)\end{array}$ & $\begin{array}{l}6 \\
(2.2)\end{array}$ & $\begin{array}{l}5 \\
(1.8)\end{array}$ & $\begin{array}{l}273 \\
100\end{array}$ \\
\hline 4. & $\begin{array}{l}\text { Long working hours could lead to break down in health } \\
\text { which affects performance and productivity negatively. }\end{array}$ & $\begin{array}{l}89 \\
(32.6)\end{array}$ & $\begin{array}{l}142 \\
(52.0)\end{array}$ & $\begin{array}{l}20 \\
(7.3)\end{array}$ & $\begin{array}{l}12 \\
(4.4)\end{array}$ & $\begin{array}{l}10 \\
(3.7)\end{array}$ & $\begin{array}{l}273 \\
100\end{array}$ \\
\hline 5. & $\begin{array}{l}\text { Sitting down in a particular position for longer than } \\
\text { necessary could lead to waist, back, neck, etc pains } \\
\text { which negatively affects performance. }\end{array}$ & $\begin{array}{l}115 \\
(42.1)\end{array}$ & $\begin{array}{l}105 \\
(38.5)\end{array}$ & $\begin{array}{c}40 \\
(14.7)\end{array}$ & $\begin{array}{l}10 \\
(3.7)\end{array}$ & $\begin{array}{l}3 \\
(1.1)\end{array}$ & $\begin{array}{l}273 \\
100\end{array}$ \\
\hline & Total & 517 & 584 & 150 & 68 & 46 & 1365 \\
\hline & Percentage of Total & $(37.9)$ & $(42.8)$ & $(11.0)$ & $(5.0)$ & $(3.4)$ & 100 \\
\hline
\end{tabular}

Note: Figures in parenthesis are percentages

: $(\mathrm{SA}=$ Strongly agree; $\mathrm{A}=$ Agree $\mathrm{D}=$ Disagree, $\mathrm{SD}=$ Strongly disagree and UND = Undecided $)$

Table 4.4 is on employees' rest time/break and its effect on their performance. The analysis presented in the table shows that on the average, 37.9 percent of the respondents strongly agreed that insufficient rest time for the workers hampers performance and productivity, 42.8 percent also agreed but not strongly, 11 percent disagreed, 5 percent strongly disagreed and 3.4 percent were undecided on all the issues raised in the section. The table shows also that there are variations across the items. For instance, whereas 33 percent and 39.6 percent strongly agreed and merely agreed with item 1, 32.6 percent and 52 percent did so respectively for item 4 .

\subsection{Test of Hypotheses}

In this section of the analysis, the hypotheses formulated to guide the objectives of the study and strengthen the analysis were re-stated and tested using the data, presented in Likert scale format in Tables 4.2, 4.3 and 4.4. All tests were carried out at 0.05 level of significance and 16 degrees of freedom (df).

\section{Hypothesis One}

$\mathrm{H}_{\mathrm{O}}$ : Inadequate physical workplace environment does not have negative and significant effect on employees performance in the organization.

$\mathrm{H}_{1}$ : Inadequate physical workplace environment have negative and significant effect on employees' performance in the organization.

Table 4.5:Summary of Chi-Square $\left(\chi^{2}\right)$ Result for Hypothesis I

\begin{tabular}{|c|c|c|c|c|c|c|c|c|}
\hline \multirow[t]{2}{*}{ Hypothesis } & \multirow{2}{*}{$\begin{array}{l}\text { Sample } \\
\text { (n) }\end{array}$} & \multirow[t]{2}{*}{ Size } & \multirow{2}{*}{$\begin{array}{l}\text { Degrees } \\
\text { freedom (df) }\end{array}$} & \multirow[t]{2}{*}{ of } & \multicolumn{2}{|c|}{ Chi-Square $\left(\chi^{2}\right)$ Values } & \multirow{2}{*}{$\begin{array}{l}\text { Sig. Level } \\
(\alpha)\end{array}$} & \multirow{2}{*}{$\begin{array}{l}\text { Decision } \\
\text { Rule }\end{array}$} \\
\hline & & & & & $\chi_{\text {cal. }}^{2}$ & $\chi_{\text {crit. }}^{2}$ & & \\
\hline $\mathrm{I}$ & 280 & & 16 & & 48.285 & 26.296 & 0.05 & Rejected \\
\hline
\end{tabular}

Note: $\chi^{2}$ cal means the calculated value of $\chi^{2}$ and $\chi^{2}$ crit. Means critical value of $\chi^{2}$.

Decision Rules I:

At 0.05 level of significance and 16 degrees of freedom, the calculated value of $\chi^{2}(48.285)$ is greater than the critical value of $\chi^{2}(26.296)$. Given this weight of evidence against the null hypothesis, it was rejected while the alternative which suggests that inadequate physical workplace environment have significant negative effect on employees performance in the organization was accepted.

Hypothesis Two

$\mathrm{H}_{\mathrm{O}}$ : High repetitive task does not have significant negative effect on employees' performance in the organization.

$\mathrm{H}_{1}$ : $\quad$ High repetitive task, have significant negative effect on employee performance in the organization.

Table 4.6:Summary of Chi-Square $\left(\chi^{2}\right)$ Result for Hypothesis II

\begin{tabular}{|c|c|c|c|c|c|c|c|c|}
\hline \multirow[t]{2}{*}{ Hypothesis } & \multirow{2}{*}{$\begin{array}{l}\text { Sample } \\
\text { (n) }\end{array}$} & \multirow[t]{2}{*}{ Size } & \multirow{2}{*}{$\begin{array}{l}\text { Degrees } \\
\text { freedom (df) }\end{array}$} & \multirow[t]{2}{*}{ of } & \multicolumn{2}{|c|}{ Chi-Square $\left(\chi^{2}\right)$ Values } & \multirow{2}{*}{$\begin{array}{l}\text { Sig. Level } \\
(\alpha)\end{array}$} & \multirow{2}{*}{$\begin{array}{l}\text { Decision } \\
\text { Rule }\end{array}$} \\
\hline & & & & & $\chi_{\text {cal. }}^{2}$ & $\chi_{\text {crit. }}^{2}$ & & \\
\hline II & 280 & & 16 & & 57.145 & 26.296 & 0.05 & Rejected \\
\hline
\end{tabular}

Note: $\chi^{2}$ cal means the calculated value of $\chi^{2}$ and $\chi^{2}$ crit. Means critical value of $\chi^{2}$. 


\section{Decision Rules II:}

At 0.05 level of significance and 16 degrees of freedom, the calculated value of $\chi^{2}(57.145)$ is greater than the critical value of $\chi^{2}(26.296)$. Consequently, we rejected the null hypothesis and conclude that high repetitive tasks have significant negative effect on employees' performance in the organization.

\section{Hypothesis Three}

$\mathrm{H}_{\mathrm{O}}$ : Insufficient rest time/break do not have significant negative effect on employees' performance in the organization

$\mathrm{H}_{1}$ : Insufficient rest time/break has significant negative effect on employees' performance in the organization.

Table 4.6:Summary of Chi-Square $\left(\chi^{2}\right)$ Result for Hypothesis III

\begin{tabular}{|c|c|c|c|c|c|c|c|c|}
\hline \multirow[t]{2}{*}{ Hypothesis } & \multirow{2}{*}{$\begin{array}{l}\text { Sample } \\
\text { (n) }\end{array}$} & \multirow[t]{2}{*}{ Size } & \multirow{2}{*}{$\begin{array}{l}\text { Degrees } \\
\text { freedom (df) }\end{array}$} & \multirow[t]{2}{*}{ of } & \multicolumn{2}{|c|}{ Chi-Square $\left(\chi^{2}\right)$ Values } & \multirow{2}{*}{$\begin{array}{l}\text { Sig. Level } \\
(\alpha)\end{array}$} & \multirow{2}{*}{$\begin{array}{l}\text { Decision } \\
\text { Rule }\end{array}$} \\
\hline & & & & & $\chi_{\text {cal. }}^{2}$ & $\chi_{\text {crit. }}^{2}$ & & \\
\hline III & 280 & & 16 & & 60.301 & 26.296 & 0.05 & Rejected \\
\hline
\end{tabular}

Note: $\chi_{\text {cal }}^{2}$ means the calculated value of $\chi^{2}$ and $\chi^{2}$ crit. Means critical value of $\chi^{2}$.

Decision Rules III:

At 0.05 level of significance and 16 degrees of freedom, the calculated value of $\chi^{2}(60.301)$ is greater than the critical value of $\chi^{2}$ (26.296). Therefore, the null hypothesis was rejected while the alternative which suggests that insufficient rest time or break has significant negative effect on employees' performance was accepted.

\subsection{Discussion of Research Findings}

The result of the first test of hypothesis indicates that inadequate physical workplace environment has significant negative effect on employees' performance in the organization. The result is consistent with that of Saleem et al (2012) when they found from their study that physical workplace interior design and furnishing is a critical step towards the achievement of enhanced employees' performance in the hospitality industry. The implication is that workplace environment ergonomic factors such as furniture and equipment, spatial office arrangement, flexibility and comfort, room temperature and air quality, illumination/lighting level in the office, etc, are office conditions that enhance performance of the employee when they are adequate. Employees working under such an environment have every reason to be satisfied and consequently show commitment towards the realization of company's goals.

Similarly, concerning the issue of repetitive tasks assignment, test result shows that it affects performance negatively. Opinions are that such repetitive tasks could lead to boredom and tiredness and even a manifestation of depressed mood while at work. Tuck (2003) found that fatigue as a result of boredom and tiredness leads to poor employee performance and consequently lose of productivity. Certainly, work or task design that allows the employee the use of his/her initiative is always more inspiring and it elicits active participation of the employee towards the realization of company's objectives. The monotonous nature of repetitive task limits the contribution of employees to the well-being of the organization.

The result of the third and final test of hypothesis in this study shows that insufficient rest time/break hampers employees' performance. The result is consistent with the finding of Desphande (2013) when he found from his study of ergonomics and its stress related issues for employees working in banks in Pakistan, that prolong exposure to physical and psychological stress leads to serious hazards to physical and mental health of bank employees. The implication is that the need to design tasks that allow for sufficient rest time to enable employees refresh and come back with new strength and vigor to face the task cannot be overemphasized. Therefore, in addition to making workplace environment conducive, employees need task design that can accommodate personal life to avoid coming down with long term conditions that may have severe effect on the employee and even the company.

\section{CONCLUSION AND RECOMMENDATIONS}

\subsection{Conclusion}

The study investigated the effect of ergonomic factors on employees' performance in Nigeria's banking sector, using selected banks in Anambra State as the study area. The ergonomic factors were measured in two main areas: physical workplace environment (furniture, equipment, lighting, noise level, room temperature and spatial arrangement) and task designs (nature of duties performed and rest time allotment). The results showed that performance and productivity of the employees would be enhanced if the physical workplace environment are adequately maintained. Similarly, employees seem to be irritated by task designs that promote repetitive assignment and insufficient rest time/break. Repetitive tasks lead to boredom and tiredness while insufficient rest time is likely to attract unpleasant health conditions both of which are not good for achieving employees expected performance.

\subsection{Recommendations}

From the findings of the study and the conclusion drawn from them, the following recommendations were made: 
1. Ergonomic factors can be used to promote improved performance and productivity from the employees in the company. The management should entice the employees by providing all the physical workplace facilities and making sure that they are in good working conditions always. This will make work a great delight for the employees who will in turn reciprocate with enhanced performance.

2. Tasks in the organization should be designed in a way that employees do not engage in repetitive assignment always but rather than a more challenging task will require the use of initiative for better outcomes to be achieved.

3. Employees need sufficient rest time that can make allowance personal time. Prolonged hours of work without enough break time will only lead to health conditions that are capable of reducing performance and consequently output in the organization.

\section{REFERENCES}

Aguinis, H. (2009). Performance management. Upper Saddle River, N.J: Pearson Prentice Hall.

Alok, S. and Shweta, J. (2011). Impact of ergonomic changes on office employees productivity. International Journal of Multidisciplinary Studies, 2(1): 151-169.

Asante, K. (2012). The impact of office ergonomics on employee performance: a study of the Ghana National Petroleum Corporation (GNPC). A Thesis in the Institute of Distance Learning, Kwame Nkrumah University of Science and Technology, Ghana.

Deouskar, N. (2017). The impact of ergonomics on productivity of the employees in the organization. International Journal of Marketing and Financial Management, 1(6): 59-63.

Deskpande, R.C. (2015). Ergonomics and its stress relating issues for the employees working in banking sector in Gujarat. S.V. Institute of Management. Kadi Sarva Vishwavidyalaya.

Hameed, A. (2009). Impact of office design on employees' productivity: a study of banking organizations of Abbottabad, Abbottabad. Journal of Public Affairs, Administration and Management, 3(1): 1-5.

Jayaweera, T. (2015). Impact of work environment on job performance, mediating role of work motivation: a study of hotel sector in England. International Journal of Business and Management, 10: 271-278.

Leblebici, D. (2012). Impact of workplace quality on employees productivity: case study of banks in Turkey. Journal of Business Economics and Finance, 1: 38-49.

Moran, G. (2012). Home office ergonomics [Online] Available from: http://www.aarp.org/work/selfemployment/info-90-20-w/home-office-ergonomics.html (Accessed May 17, 2012).

Pawar, P.Y. and Kheadkar, E.B. (2016). Comparative study about organizational ergonomics between IT Sector and Banking Sector. International Research Journal of Multidisciplinary Studies, 2(3): 1-5.

Pickson, R.B., Bannerman, S. and Ahwireng, P.O. (2017). Investigating the effect of ergonomics on employee productivity: a study of the butchering and trimming line of Pioneer Food Cannery, Ghana. Modern Economy, 8: $1561-1574$.

Roelofsen, P. (2002). The impact of office environment on employees performance: the design of the workplace as a strategy for productivity enhancement. Journal of Facilities Management, 1: 247-264.

Saleem, A., Shah, A., Zaman, K., Arif, M., Shehzad, K. and Ullah, I. (2012). The impact of interior physical environment on academicians' productivity in Pakistani higher education institutions. Iranian Journal of Management Studies (IJMS), 5: 25 - 46.

Sekar, C. (2011). Workplace environment and its impact on organizational performance in public sector organizations. International Journal of Enterprise Computing and Business System International Systems, 1(1): 203-215.

Stonner, J., Freeman, R. and Gilbert, Jr. (2006). Management, 6th edition. Pg 366-367.

Taiwo, A. (2010). The influence of work environment on employee performance: a study of selected oil and gas industries in Lagos State, Nigeria. African Journal of Business Management, 4(3): 290-307.

Tucker, P. (2003). The impact of rest break on accident risk, fatigue and performance. A Review of Work and Stress, 17(12): 123-137.

Vinalanathan, K. and Babu, R.T. (2017). A study of the effect of ergonomics on computer operating office workers in India. Journal of Ergonomics, 7(5): 1-4.

Yankson, E. (2012). The effect of health and safety standards on productivity in Ghana Rubber Estates Limited. Unpublished Master's Thesis, Institute of Distance Learning, Kwama Nkruma University of Science and Technology, Kumasi, Ghana.

Zafir, M.M., Syed, S.A., Shaza, M.A. and Norliza, A. T. (2011). Ergonomics and work stress issues in banking sector. Australian Journal of Basic and Applied Sciences, 5(9): 1301-1309. 


\section{Appendix I \\ Survey Instrument}

Instruction: Please tick $[\checkmark]$ as appropriate in the boxes provided

Section I: Personal Data of the Respondents

1. Gender: Male [1]; Female [2]

2. Age Bracket: $18-27$ [ ]

$28-37[$ ]

$38-47[]$

$48-57[]$

3. Educational Attainment:

58 and above [ ]

4. Organizational Tenure

$\begin{array}{ll}\text { Diploma } & {[} \\ \text { First degree } & {[} \\ \text { Professional Cert. [ ] } \\ \text { Masters degree } & {[\text { ] }} \\ \text { Ph.D } & {[\text { ] }}\end{array}$

$\begin{array}{ll}\text { Less than } 5 \text { years } & {[\text { ] }} \\ \text { 5-10 years } & {[\text { ] }} \\ 11-15 \text { years } & {[\text { ] }} \\ 16 \text { and above years } & {[\text { ] }}\end{array}$

Physical Workplace Environment and Employee Performance

\begin{tabular}{|c|c|c|c|c|c|c|c|}
\hline \multirow[t]{2}{*}{$\mathrm{S} / \mathrm{N}$} & \multirow[t]{2}{*}{ Item } & \multicolumn{5}{|c|}{ Alternative Responses } & \multirow[t]{2}{*}{ Total } \\
\hline & & $\mathrm{SA}$ & A & $\mathrm{D}$ & $\mathrm{SD}$ & UND & \\
\hline 1. & $\begin{array}{l}\text { When one office is sufficiently equipped with appropriate and } \\
\text { standard furnitures, the employees will perform optimally. }\end{array}$ & & & & & & \\
\hline 2. & $\begin{array}{l}\text { In this age of IT, functional computer units and other IT equipment } \\
\text { are very necessary for effective performance. }\end{array}$ & & & & & & \\
\hline 3. & $\begin{array}{l}\text { When an office is properly illuminated couple with adequate air } \\
\text { flow, workers would be happy in the office. }\end{array}$ & & & & & & \\
\hline 4. & $\begin{array}{l}\text { With good spatial arrangement in the office, work is made a great } \\
\text { delight for the workers. }\end{array}$ & & & & & & \\
\hline 5. & $\begin{array}{l}\text { Workplace flexibility in terms of access to easy communication and } \\
\text { other accessories reduces job hazards. }\end{array}$ & & & & & & \\
\hline
\end{tabular}

Note: $(\mathrm{SA}=$ Strongly agree; $\mathrm{A}=$ Agree; $\mathrm{D}=$ Disagree; $\mathrm{SD}=$ Strongly disagree and UND = Undecided)

High Repetitive Tasks and Employees' Performance

\begin{tabular}{|l|l|l|l|l|l|l|}
\hline S/N & \multicolumn{1}{|c|}{ Item } & \multicolumn{3}{|c|}{ Alternative Responses } & Total \\
\cline { 3 - 6 } & & SA & A & D SD & UND & \\
\hline 1. & $\begin{array}{l}\text { Job designs that are highly repetitive in nature does not give } \\
\text { employees room for taking initiative and it negatively affects } \\
\text { employees performance. }\end{array}$ & & & & & \\
\hline 2. & $\begin{array}{l}\text { Office works that are physically exhaustive reduces employees } \\
\text { performance and productivity in the service sector. }\end{array}$ & & & & & \\
\hline 3. & $\begin{array}{l}\text { Repetitive tasks for a long time does not encourage employees' } \\
\text { development and it impedes performance. }\end{array}$ & & & & \\
\hline 4. & $\begin{array}{l}\text { Repetitive tasks demotivates and some times it leaves task } \\
\text { uncompleted thereby reducing productivity. }\end{array}$ & & & & & \\
\hline 5. & $\begin{array}{l}\text { Work design that is not in conformity with the desires of the worker } \\
\text { leads to health issues. }\end{array}$ & & & & \\
\hline
\end{tabular}

Note: (SA = Strongly agree; $\mathrm{A}=$ Agree; $\mathrm{D}=$ Disagree; $\mathrm{SD}=$ Strongly disagree and UND = Undecided) 
Insufficient Rest Time Break and Employees' Performance

\begin{tabular}{|c|c|c|c|c|c|c|c|}
\hline \multirow[t]{2}{*}{$\mathrm{S} / \mathrm{N}$} & \multirow[t]{2}{*}{ Item } & \multicolumn{5}{|c|}{ Alternative Responses } & \multirow[t]{2}{*}{ Total } \\
\hline & & $\mathrm{SA}$ & A & $\mathrm{D}$ & SD & UND & \\
\hline 1. & $\begin{array}{l}\text { When faced with long working hours, employees feel dissatisfied } \\
\text { and it negatively affects performance. }\end{array}$ & & & & & & \\
\hline 2. & $\begin{array}{l}\text { Long hours of work in front of a computer monitor raises some } \\
\text { health issues with the eyes of the worker. }\end{array}$ & & & & & & \\
\hline 3. & $\begin{array}{l}\text { Insufficient rest time/break does not give room for proper relaxation } \\
\text { to refresh and come back for good performance. }\end{array}$ & & & & & & \\
\hline 4. & $\begin{array}{l}\text { Long working hours could lead to break down in health which affects } \\
\text { performance and productivity negatively. }\end{array}$ & & & & & & \\
\hline 5. & $\begin{array}{l}\text { Sitting down in a particular position for longer than necessary could } \\
\text { lead to waist, back, neck, etc pains which negatively affects } \\
\text { performance. }\end{array}$ & & & & & & \\
\hline
\end{tabular}

Note: $(\mathrm{SA}=$ Strongly agree; $\mathrm{A}=$ Agree; $\mathrm{D}=$ Disagree; $\mathrm{SD}=$ Strongly disagree and UND = Undecided)

\section{Appendix II}

Estimation Reliability Coefficients through the Spearman Rank Order Correlation Coefficient $r=1-\frac{6 \sum d^{2}}{n\left(n^{2}-1\right)}$

Where:

$$
\begin{array}{ll}
\mathrm{r} & =\text { the coefficient to be estimated } \\
\mathrm{n} & =\text { number of response options } \\
\mathrm{d} & =\text { difference in rank order }
\end{array}
$$

1 and $6=$ constants

The value of the coefficient ' $r$ ' ranges from -1 to +1 .

Reliability Estimation for Research Question II

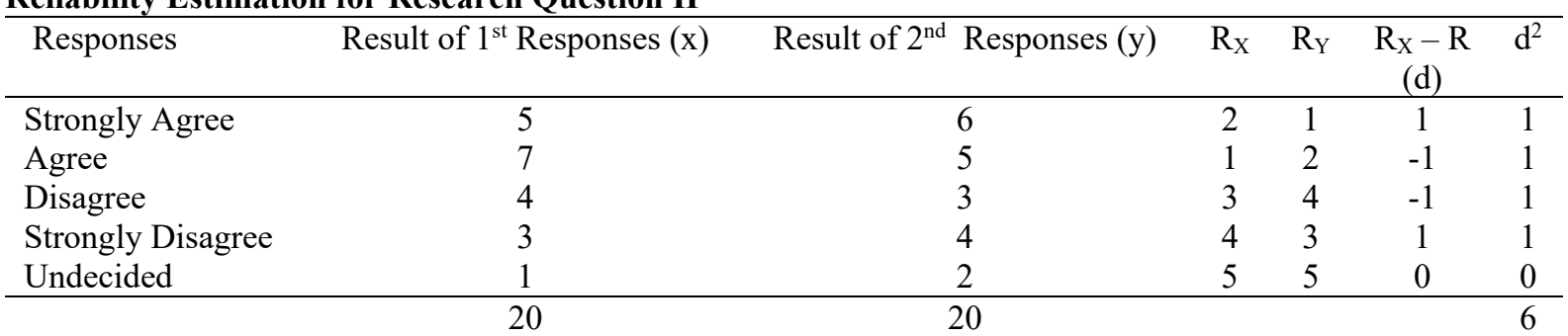

$r=1-\frac{6(4)}{5\left(5^{2}-1\right)}=1-\frac{24}{120}=0.80$

Reliability Estimation for Research Question II

\begin{tabular}{|c|c|c|c|c|c|c|}
\hline & & & & & $(d$ & \\
\hline Strongly Agree & 7 & 6 & 1 & 1 & 0 & 0 \\
\hline Agree & 6 & 5 & 2 & 2 & 0 & 0 \\
\hline Disagree & 4 & 3 & 3 & 5 & -1 & 1 \\
\hline Strongly disagree & 2 & 4 & 4 & 3 & 1 & 1 \\
\hline Undecided & 1 & 2 & 5 & 5 & 0 & 0 \\
\hline Total & 20 & 20 & & & & 2 \\
\hline
\end{tabular}

Response Options Result of 1st responses

(x) 
Reliability Estimation for Research Question III

\begin{tabular}{lcccccc}
\hline Responses & $\begin{array}{c}\text { Result of 1 } \\
\text { Responses (x) }\end{array}$ & $\begin{array}{c}\text { Result of 2 } \\
\text { Responses (y) }\end{array}$ & $\mathrm{R}_{\mathrm{X}}$ & $\mathrm{R}_{\mathrm{Y}}$ & $\begin{array}{c}\mathrm{R}_{\mathrm{X}}-\mathrm{R} \\
(\mathrm{d})\end{array}$ & $\mathrm{d}^{2}$ \\
\hline Strongly Agree & 5 & 7 & 2 & 1 & 1 & 1 \\
Agree & 6 & 5 & 1 & 2 & -1 & 1 \\
Disagree & 4 & 3 & 3 & 4 & -1 & 1 \\
Strongly Disagree & 3 & 4 & 4 & 3 & 1 & 1 \\
Undecided & 2 & 1 & 5 & 5 & 0 & 0 \\
\hline & 20 & 20 & & & & 4 \\
\hline
\end{tabular}

$r=1-\frac{6(4)}{5\left(5^{2}-1\right)}=1-\frac{24}{120}=0.80$

\section{Theoretical Background of the Chi-square $\left(\chi^{2}\right)$}

Appendix III

The relationship between variables were examined using Chi-square $\left(\chi^{2}\right)$ test of association in this section. The test procedure and actual estimation are shown below:

We calculate an overall measure of discrepancy between the observed and expected values. We therefore compare this measure with some theoretical values of the same Chi-square $\left(\chi^{2}\right)$ (Oyeka, 1996).

Test Statistics of Chi-Square $\left(\chi^{2}\right)$

$\chi^{2}=\frac{\sum(O-E)^{2}}{E} \sim \chi_{(\mathrm{r}-1)(\mathrm{c}-1)}^{2}$

Where:

$\mathrm{O}=$ Observed frequency and

$\mathrm{E}=$ Expected frequency

And $E=\frac{N_{i} \times N_{j}}{N_{. .}}$

Where:

Where:

$$
\begin{array}{ll}
\mathrm{N}_{\mathrm{i}} & =\text { Row total } \\
\mathrm{N}_{\mathrm{j}} & =\text { Column total } \\
\mathrm{N}_{. .} & =\text {Overall total }
\end{array}
$$

$r$ denote row

c denote column

$\therefore(\mathrm{r}-1)(\mathrm{c}-1)=$ degrees of freedom $(\mathrm{df})$ and

$(\alpha)=$ level of significance

\section{Decision Rule:}

Whenever $\chi_{\mathrm{c}}^{2} \geq \chi_{(\mathrm{r}-1)(\mathrm{c}-1)}^{2}$

Where $\chi_{\mathrm{c}}^{2}=$ Chi-square $\left(\chi^{2}\right)$ Calculated and

$\chi_{(\mathrm{r}-1)(\mathrm{c}-1)}^{2}=$ Chi-square $\left(\chi^{2}\right)$ tabulated,

reject $\mathrm{H}_{0}$ and accept $\mathrm{H}_{1}$.

1. Chi-square $\left(\chi^{2}\right)$ Calculation for Hypothesis I

$\chi_{\text {cal }}^{2}=\frac{\sum(O-E)^{2}}{E}$

$=\frac{(92-107)^{2}}{107.2}+\frac{(136-124)^{2}}{124}+\cdots+\frac{(9-8.6)^{2}}{8.6}$

$=2.10+01.16+\cdots+0.02$

$\chi_{\text {cal. }}^{2}=48.285$

$\chi_{\text {crit. }}^{2}=26.296$

Hence the Null hypothesis was rejected and the alternative accepted.

2. Chi-square $\left(\chi^{2}\right)$ Calculation for Hypothesis II

$\chi_{c a l}^{2}=\frac{\sum(O-E)^{2}}{E}$

$=\frac{(112-110.4)^{2}}{110.4}+\frac{(121-119.4)^{2}}{119.4}+\cdots+\frac{(7-2.2)^{2}}{2.2}$

$=0.02+0.00+\cdots+10.47$

$\chi_{\text {cal. }}^{2}=57.145$

$\chi_{\text {crit. }}^{2}=26.296$ 
3. Chi-square $\left(\chi^{2}\right)$ Calculation for Hypothesis III

$\chi_{\text {cal }}^{2}=\frac{\sum(O-E)^{2}}{E}$

$=\frac{(90-103.4)^{2}}{103.4}+\frac{(108-116.8)^{2}}{116.8}+\cdots+\frac{(3-9.2)^{2}}{9.2}$

$=1.74+0.66+\cdots+4.17$

$\chi_{\text {cal. }}^{2}=60.301$

$\chi_{\text {crit. }}^{2}=26.296$

Hence the null hypothesis was rejected and the alternative accepted. 